\title{
The Effect of Service Quality on Customer Loyalty with Brand Images and Customer Satisfaction as Mediation
}

\author{
Adhitya Narotama \\ Faculty of Economics, Brawijaya University, Malang \\ adhitya.narotama@gmail.com
}

\begin{abstract}
This study aims to determine the effect of service quality on customer loyalty with brand images and customer satisfaction as mediation. This research is a quantitative correlational type using non probability sampling. The number of sample are 400 customers of BRI Branch Office on Soekarno Hatta Malang. Data is processed using Partial Least Square (PLS) method. The results show: 1) The service quality has a significant effect on customer satisfaction; 2) The service quality has a significant effect on brand images; 3) The service quality has no effect on customer loyalty; 4) The customer satisfaction has a significant effect on customer loyalty; 5) The brand images has no effect on customer loyalty; 6) The effect of service quality on customer loyalty through customer satisfaction is a significant.; 7) The effect of service quality on customer loyalty through brand images is an insignificant.
\end{abstract}

Keywords : Brand Images, Customer Satisfaction, Loyalty, Service Quality

\section{INTRODUCTION}

In the era of globalization, competition in the field of banking services becomes more tigher. Banks require a strategy of retaining customers through the quality of good service, including faster service, friendly service, and high empathy for customers. Poor services can make customers move to other banks that have better services. According of Harianto and Subagio (2013), the higher the level of consumer satisfaction, the higher the level of customer loyalty. Based on the above, the quality of services prioritizes aspects of customer satisfaction. Quality of service has a close relationship with customer satisfaction. In turn, customer satisfaction can create customer loyalty to companies that give satisfaction of service quality. The statement shows that by maintaining service quality, banks will be able to maintain customer loyalty.

Customer loyalty can also be influenced by the level of awareness of the brand image of the bank. In the research of Ayu and Made (2015), found that brand images have a positive and significant effect on customer satisfaction. It can be concluded that the more attached the brand images in the customer's mind, the higher satisfaction the customer feel. BRI is one of the national banks having brand images is quite good. But in this era of tight banking competition it is possible that the customer will move to another bank if the customer rarely hears or sees something about Bank BRI. The research of Ren-Fang Chao, Tai-Chi Wu and Wei-Ti Yen (2015), analyzed the service of quality, brand image and customer satisfaction with customer loyalty in the relationship between service quality, 
customer satisfaction, and customer loyalty, found that service quality does not has a positive effect on customer loyalty. Instead, this relationship is mediated by customer satisfaction, which is shown in an industry.

The high level of customer awareness of brand image will affect customer loyalty. The frequent appearance of brand image on the market in any form, will help bank to increase the level of awareness brand image and make their customers loyal. This is related with research from Grace Kavengi Onyancha (2013) which examined the relationship between brand image, customer satisfaction and loyalty in Kenyan commercial banks. The research found that service satisfaction was the key to loyalty. There was a positive relationship between customer satisfaction and loyalty, it means that if banking service users are satisfied, they will become loyal customers. These findings indicate the importance of brand image for banking customers as service quality, customer satisfaction with loyalty levels.

The level of competition in banking services in Malang City is tight. Each bank competes to meet customer needs in order to achieve high satisfaction from each of their customers. These are such as the availability of ATM machines, internet banking applications, several credit offers for Micro Small Enterprises (SMEs), responsiveness and empathy from customer service and others. These facilities are those that influence customer loyalty to become business partners in long term. Based on the background, it is necessary to conduct a study of the relationship between service quality, brand images, customer satisfaction, and customer loyalty. Through this research, it is expected to be able to show the effect of service quality on customer loyalty with brand images and customer satisfaction as mediation.

\section{Consumer Behavior}

According to Kotler and Keller (2008: 214), consumer behavior is the study of how individuals, groups and organizations choose, buy, use and place goods, services, ideas or experiences to satisfy their wants and needs. While according to Hawkins, Best and Coney (Suryani, 2008: 6), consumer behaviour is the study of individuals, groups or organizations and the process they use to select, secure, use and dispose of products, services, experiences or ideas to satisfy need and the impact of these processes on the consumer and society. Referring to Hawkins et al's opinion, it means that consumer behavior is a study of how individuals, groups and organizations and processes are carried out to select, secure, use and stop products, services, experiences or ideas to satisfy their needs and their impact on consumers and society.

\section{Customer Loyalty}

Kotler and Keller (2012) define loyalty as a firmly held commitment to buy or subscribe to certain products or services in the future despite the influence of the situation and marketing efforts that have the potential to cause behavioral shifts. Maintaining customer loyalty means that companies spend less cost to keep their customer than cost to get one new customer. Loyalty will provide many benefits for the company, including the repetition of purchases and recommendations regarding the brand to friends and acquaintances.

\section{Service Quality}

Service is defined as an action or performance given by someone to someone else. In the manufacturer, quality is conformity to the specification, the manufacturer gives certain tolerances that are specified for the critical dimensions of each part produced. For the consumer, quality is the value, how well a product or service presents a purpose intended with the level of price that consumers are willing to pay (Kotler in Ika, 2016). Service quality is defined as the customer's assessment of the superiority or privilege of a product or service as a whole (Zeithaml in Mukarom, 2012). 


\section{Customer Satisfaction}

According to Kotler (2012), satisfaction is a happy feeling of someone who appears after comparing the performance of the product with the expected performance. If performance is below expectations, customers are not satisfied.,but if performance meets expectations, customers are satisfied and if performance exceeds expectations, customers are very satisfied or happy. According to Engel in Lovenia (2012), customer satisfaction is a full-time evaluation where alternatives are chosen at least equal to or exceed customer expectations, while dissatisfaction arises when the results do not meet expectations.

\section{Brand Images}

A brand is a name, term, sign, symbol, or design or a combination of all that aims to identify goods and services of the company and to distinguish their products from competitors (Kotler in Andrologi, 2014). According to the brand law no.15 of 2001 the brand is a sign in the form of images, names, words, numbers, letters, numbers, arrangements or combinations of these elements which have distinguishing features and are used for trading activities of goods and services.

\section{Bank}

According to the Republic of Indonesia Law No.10 of 1998 on banking, banks is a business entity that collects funds from the public in the form of deposits and distributes them to the public in the form of loans or other forms in order to improve living standards many people.

In addition, according to Kasmir (2014: 8), bank is a financial institution whose main activities are receiving deposits, savings and deposits. Then the bank is also known as a place to borrow money (credit) for people who need it. Banks are also known as a place to exchange money, move money or accept all kinds of payments and deposits such as electricity, telephone, water, taxes, tuition fees, and other payments.

\section{METHOD}

This research included in the type of quantitative correlations, to determine whether there is a relationship between two or more variables, and how far the correlation between the variables studied. According to Arikunto (2010), judging from the relationship between variables, this study was also included in the study of causality. Casual research is done to explain the relationship between variables, one variable causes or determines the value of another variable (Cooper and Schindler, 2006). The unit of analysis is customer of the BRI Soekarno Hatta Branch Office Malang.

The primary data is collected by issue a questionnaire about service quality, brand images, customer satisfaction, and customer loyalty for customers of BRI Branch Office on Malang Soekarno Hatta. While secondary data is obtained indirectly from research objects such as bank profiles, bank history, products/services banks, journal references and other supporting literature.

In this study the sampling technique used is non probability sampling, while the sampling method used in this study is systematic sampling with a method only the first element of the sample is chosen randomly while the next elements are selected systematic according to a certain pattern/criteria. The criteria of respondent are : 1) customers have savings for three (3) years or more, 2) the customer is at least 25 years old.

In this study the number of samples used was determined based on Roscoe's theoretical formula in Sugiyono's book (2012: 91). In this study, researchers took a sample of 400 which were believed to have exceeded the requirements in Roscoe's theory. As a general rule, sample sizes between 30 and 500 can be effective depending on how the sampling is used and the research questions used. The instrument used in this study is a questionnaire that lists questions. The scale used in this study is the Likert Scale (interval). This scale is the most popular for attitude measurement because it is easy for researchers to prepare 
questionnaires and it is easy for respondents to respond to questions (Simamora, 2004).

The next step is to test the instrument, then test the validity and reliability test. The object of the research is the BRI Branch Office on Malang Soekarno Hatta while the time for conducting the research was conducted in June 2018. The technique of collecting data was the survey method. The approach to data collection uses the cross sectional method. Data analysis in this study using Partial Least Square (PLS) method. PLS can be used on each type of data scale (nominal, ordinal, interval, ratio) and the terms of a more flexible assumption. PLS is also used to measure the relationship of each indicator to its construct. In addition, in the PLS a bootstrapping test can be performed on the structural model which is the outer model and inner model.

The purpose of the research are : 1) to analyze the effect of service quality on on customer loyalty, 2) to analyze the influence of brand images on customer loyalty, 3) to analyze the influence of customer satisfaction on customer loyalty, 4) to analyze the influence of service quality on brand images, 5) to analyze the influence of service quality on customer satisfaction, 6) to analyze brand images as mediation of the influence service quality on customer loyalty, 7) to analyze customer satisfaction as a mediation of the influence service quality on customer loyalty.

\section{RESULT AND DISCUSSION}

The measurement model based on calculations using the PLS program in this research as below :
Table 1. Summary of Evaluation of the Measurement Model / Outer Model

\begin{tabular}{|c|c|c|c|c|c|c|c|c|}
\hline \multirow{3}{*}{$\begin{array}{c}\text { Latent } \\
\text { variable }\end{array}$} & \multirow{3}{*}{$\begin{array}{c}\text { Observ } \\
\text { ed } \\
\text { variabl } \\
\text { e }\end{array}$} & \multicolumn{5}{|c|}{ Convergent Validity } & \multirow{2}{*}{\multicolumn{2}{|c|}{$\begin{array}{c}\text { Composite } \\
\text { Reliability } \\
(\mathrm{CR}>0,7)\end{array}$}} \\
\hline & & \multicolumn{2}{|c|}{ (LF $>0,5=$ Valid $)$} & \multirow{2}{*}{ 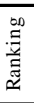 } & \multicolumn{2}{|c|}{$\overline{(\mathrm{AVE}>0,5=\text { Valid })}$} & & \\
\hline & & $\begin{array}{l}\text { Loading } \\
\text { Factor }\end{array}$ & $\begin{array}{l}\text { Informat } \\
\text { ion }\end{array}$ & & AVE & $\begin{array}{c}\text { Conclusi } \\
\text { on }\end{array}$ & CR & $\begin{array}{c}\text { Informat } \\
\text { ion }\end{array}$ \\
\hline \multirow{5}{*}{$\begin{array}{l}\text { Service } \\
\text { Quality } \\
\text { (X) }\end{array}$} & $\mathrm{X} 1$ & 0,57 & Valid & 5 & \multirow{5}{*}{0,51} & \multirow{5}{*}{ Valid } & \multirow{5}{*}{0,835} & \multirow{5}{*}{ Reliable } \\
\hline & $\mathrm{X} 2$ & 0,697 & Valid & 3 & & & & \\
\hline & $\mathrm{X} 3$ & 0,861 & Valid & 1 & & & & \\
\hline & $\mathrm{X} 4$ & 0,812 & Valid & 2 & & & & \\
\hline & X5 & 0,581 & Valid & 4 & & & & \\
\hline \multirow{5}{*}{$\begin{array}{l}\text { Customer } \\
\text { Satisfacti } \\
\text { on (M1) }\end{array}$} & M1.1 & 0,718 & Valid & 3 & \multirow{5}{*}{0,522} & \multirow{5}{*}{ Valid } & \multirow{5}{*}{0,843} & \multirow{5}{*}{ Reliable } \\
\hline & M1.2 & 0,869 & Valid & 1 & & & & \\
\hline & M1.3 & 0,764 & Valid & 2 & & & & \\
\hline & M1.4 & 0,65 & Valid & 4 & & & & \\
\hline & M1.5 & 0,576 & Valid & 5 & & & & \\
\hline \multirow{4}{*}{$\begin{array}{l}\text { Brand } \\
\text { Images } \\
\text { (M2) }\end{array}$} & M2.1 & 0,82 & Valid & 1 & \multirow{4}{*}{0,573} & \multirow{4}{*}{ Valid } & \multirow{4}{*}{0,843} & \multirow{4}{*}{ Reliable } \\
\hline & M2.2 & 0,749 & Valid & 2 & & & & \\
\hline & M2.3 & 0,737 & Valid & 3 & & & & \\
\hline & M2.4 & 0,72 & Valid & 4 & & & & \\
\hline \multirow{4}{*}{$\begin{array}{c}\text { Customer } \\
\text { Loyalty } \\
\text { (Y) }\end{array}$} & Y1 & 0,761 & Valid & 2 & \multirow{4}{*}{0,566} & \multirow{4}{*}{ Valid } & \multirow{4}{*}{0,838} & \multirow{4}{*}{ Reliable } \\
\hline & Y2 & 0,705 & Valid & 3 & & & & \\
\hline & Y3 & 0,846 & Valid & 1 & & & & \\
\hline & Y4 & 0,689 & Valid & 4 & & & & \\
\hline
\end{tabular}

Source: Primary Data Processed, 2018

Based on the table 1, all values of loading factors in variables are greater than 0.5 , which means the indicators are declared valid, even though there is one item that is declared invalid but the item can still be maintained because overall it is good, this is proven by the AVE value $>0.5$ (Valid), and the value of Composite Reliability has a value greater than 0,700 (Reliable). Thus, in general, the results of local optimization (outer model) are declared good and feasible to continue the analysis.

Table 2. Coefficient of Determination

\begin{tabular}{|c|c|c|c|}
\hline \multicolumn{3}{|c|}{ Effect } & \multirow{2}{*}{$\begin{array}{c}\text { R Square } \\
0,177\end{array}$} \\
\hline $\begin{array}{l}\text { Service } \\
\text { Quality (X) }\end{array}$ & $-->$ & $\begin{array}{l}\text { Customer } \\
\text { Satisfaction (M1) }\end{array}$ & \\
\hline $\begin{array}{l}\text { Service } \\
\text { Quality (X) }\end{array}$ & $-->$ & Brand Images (M2) & 0,394 \\
\hline $\begin{array}{l}\text { Service } \\
\text { Quality (X) }\end{array}$ & $-->$ & \multirow{3}{*}{$\begin{array}{l}\text { Customer } \\
\text { Loyalty (Y) }\end{array}$} & \multirow{3}{*}{0,587} \\
\hline $\begin{array}{l}\text { Customer } \\
\text { Satisfaction } \\
\text { (M1) }\end{array}$ & $-->$ & & \\
\hline $\begin{array}{l}\text { Brand Images } \\
\text { (M2) }\end{array}$ & $-->$ & & \\
\hline
\end{tabular}

Source: Primary Data Processed, 2018

Based on table 2, the determination coefficient (R-square) obtained from the service quality model (X) on customer 
satisfaction (M1) is 0.177 , it can be explained that the accuracy of service quality (X) measurement for customer satisfaction (M1) is $17.69 \%$ and the remaining $82,31 \%$ get effects from other variables outside of this research. The determination coefficient (Rsquare) obtained from service quality (X) on brand images (M2) is 0.394 , so it can be explained that the accuracy of service quality measurement (X) for brand images (M2) is $39.35 \%$ and the remaining $60,65 \%$ gets effects from other variables outside of research. The determination coefficient (Rsquare) obtained from the service quality model (X), customer satisfaction (M1) and brand images (M2) on customer loyalty (Y) is 0.587 , so that it can be explained that the accuracy of service quality (X), satisfaction customer (M1) towards customer loyalty (Y) of $58.68 \%$ and the remaining $41.32 \%$ get effects from other variables outside the research. The results of the calculation of the total determination coefficient are as follows.

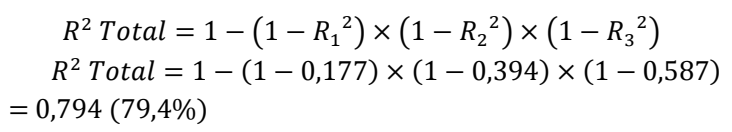

Total determination coefficient obtained from the structural model is 0.794 . It means $79.4 \%$ of the data possessed can be explained by the formed path model and the remaining $20.6 \%$ is explained by other factors outside the research. The results of standard measurements of the inner model testing criteria based on the total determination coefficient are as follows.

Table 3. Level of Strength of Structural Models (Global Optimization)

\begin{tabular}{ccccc}
\hline \multirow{2}{*}{ No } & \multicolumn{2}{c}{ Standard R-Square Criteria } & \multirow{2}{\text{R-}}{$\begin{array}{c}\text { Square } \\
\text { Total }\end{array}$} & $\begin{array}{c}\text { Inform } \\
\text { ation }\end{array}$ \\
\cline { 2 - 3 } & Interval & Category & & \\
\cline { 1 - 3 } 0 & $0,000-0,299$ & Very weak & & \\
\hline 2 & $0,300-0,499$ & Weak & Strong \\
\cline { 1 - 3 } 3 & $0,500-0,699$ & Moderate & & \\
\hline 4 & $\mathbf{0 , 7 0 0 - 1 , 0 0 0}$ & Strong & & \\
\hline
\end{tabular}

Source: Primary Data Processed, 2018
Based on table 3, the total determination coefficient is 0.794 , where the value is in the range of $0.700-1,000$. Based on the standard R-Square testing criteria, the constructed model is relatively strong to confirm the theory. So that the use of the path construction is declared appropriate and feasible to test the hypothesis.

Table 4. Results of Estimates and Testing of Hypothesis

\begin{tabular}{|c|c|c|c|c|c|}
\hline \multicolumn{3}{|c|}{ Effect between Latent variables } & \multirow{2}{*}{$\begin{array}{c}\text { Path } \\
\text { Coeffic } \\
\text { ient } \\
\end{array}$} & \multirow{2}{*}{$\begin{array}{c}\mathrm{t}- \\
\text { value }\end{array}$} & \multirow[b]{2}{*}{ Conclusion } \\
\hline $\begin{array}{c}\text { Cause } \\
\text { Variable }\end{array}$ & $-->$ & Variable Effect & & & \\
\hline $\begin{array}{c}\text { Service } \\
\text { Quality (X) } \\
\end{array}$ & $-->$ & $\begin{array}{c}\text { Customer } \\
\text { Satisfaction (M1) } \\
\end{array}$ & 0,421 & 4,728 & Significant \\
\hline $\begin{array}{c}\text { Service } \\
\text { Quality (X) }\end{array}$ & $-->$ & $\begin{array}{c}\text { Brand } \\
\text { Images (M2) }\end{array}$ & 0,627 & 10,72 & Significant \\
\hline $\begin{array}{c}\text { Service } \\
\text { Quality (X) }\end{array}$ & $-->$ & $\begin{array}{l}\text { Customer } \\
\text { loyalty (Y) }\end{array}$ & 0,084 & 0,474 & $\begin{array}{c}\text { Not } \\
\text { Significant }\end{array}$ \\
\hline $\begin{array}{c}\text { Customer } \\
\text { Satisfaction } \\
\text { (M1) }\end{array}$ & $-->$ & $\begin{array}{l}\text { Customer } \\
\text { loyalty (Y) }\end{array}$ & 0,695 & 4,342 & Significant \\
\hline $\begin{array}{c}\text { Brand } \\
\text { Images (M2) }\end{array}$ & $-->$ & $\begin{array}{l}\text { Customer } \\
\text { loyalty (Y) }\end{array}$ & 0,046 & 0,324 & $\begin{array}{c}\text { Not } \\
\text { Significant }\end{array}$ \\
\hline
\end{tabular}

Source: Primary Data Processed, 2018

Based on table 4 above, it is known that: 1$)$ The service quality variable (X) has a positive and significant effect on customer satisfaction (M1). It means the higher the quality of service, the higher the customer satisfaction, 2) The service quality variable (X) has a positive and significant effect on brand images (M2). It means that the increasing of quality service will increase the brand image; 3) The service quality variable (X) has a positive effect on customer loyalty (Y), but the effect is not significant; 4) The customer satisfaction variable (M1) has a positive and significant effect on customer loyalty (Y). It means that the increasing of customer satisfaction will raise the variable customer loyalty; 5) The brand images (M2) has a positive effect on customer loyalty (Y), but the effect is not significant. 
Figure 1. PLS Path Chart (Outer and Inner

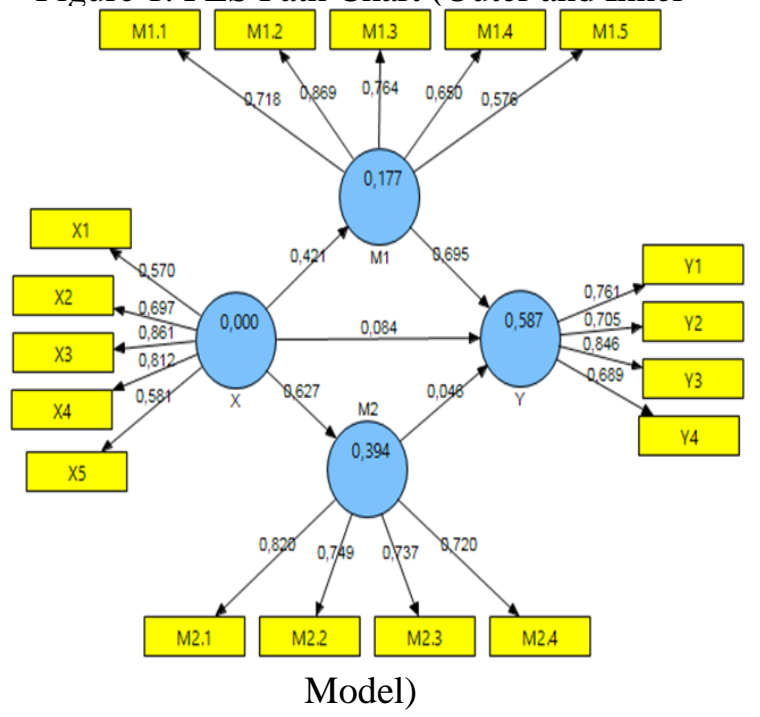

Based on the Path Diagram, it is known That the most dominant factor in effecting customer loyalty (Y) is customer satisfaction (M1,) with the highest path coefficient of 0.695. This means that customer satisfaction (M1) is the dominant varible in giving effect to customer loyalty (Y). While the customer satisfaction variable (M1) is effected by service quality $(\mathrm{X})$, where the most dominant indicators in measuring the quality of service (X) is guarantee/assurance (X3), with the highest factor loading of 0.861 . It indicates if the decision maker wants to increase the value of service quality (X), the statistic recommendation prioritizes to increase the value of assurance (X3).

Table 5. Indirect Effects Between Latent Variables

\begin{tabular}{|c|c|c|c|c|}
\hline Indirect Effects & Calculation & Results & t-count & Information \\
\hline $\begin{array}{l}\text { Service Quality (X) to } \\
\text { Customer Loyalty (Y) } \\
\text { through Customer } \\
\text { Satisfaction (M1) }\end{array}$ & $0,421 \times 0,695$ & 0,293 & 3,198 & Significant \\
\hline $\begin{array}{l}\text { Service Quality (X) to } \\
\text { Customer Loy alty (Y) } \\
\text { through Brand Images } \\
\text { (M2) }\end{array}$ & $0,627 \times 0,046$ & 0,029 & 0,324 & $\begin{array}{c}\text { Not } \\
\text { Significant }\end{array}$ \\
\hline
\end{tabular}

Source: Primary Data Processed, 2018

If the decision maker wants to increase the value of customer loyalty (Y), it can prioritize customer satisfaction (M1) as the main mediator in increasing the value of service quality $(X)$, because the effect of service quality (X) on customer loyalty (Y) through customer satisfaction (M1) is 0.293 with t count of $3.198>1.96$ (significant).

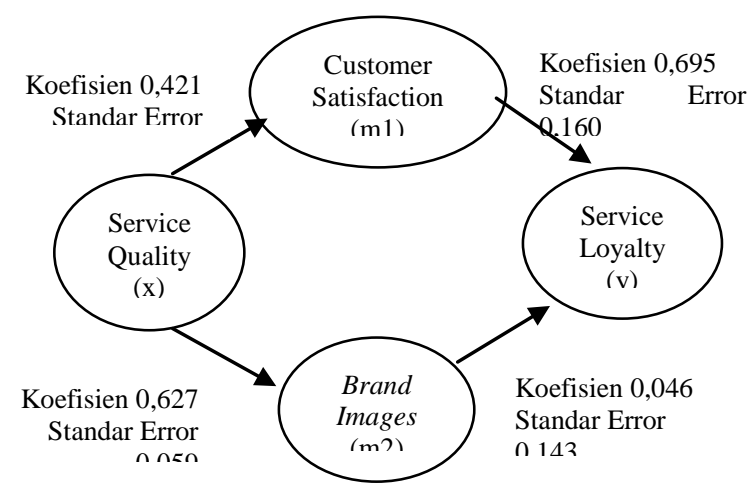

Figure 2. Mediator Model

Service quality does not have a significant effect on customer loyalty, where the path coefficient obtained is 0.084 with a tvalue of 0.474 . This happens because each bank has the same Standard Operating Procedure (SOP) so that customers consider it as a natural thing.

Brand images do not have a significant effect on customer loyalty where the path coefficient obtained is 0.046 with a t-value of 0.324 . This is because loyal customers of the BRI Branch Office on Soekarno Hatta Malang are those who repurchase the same brand, only consider the same brand and do not seek information at all about other brands.

Customer satisfaction (M1) has a positive effect on customer loyalty (Y). It means the higher customer satisfaction (M1) will consequently raise customer loyalty variable (Y), where the path coefficient obtained is 0.695 with a t-value of 4.342 . This is because the services provided by BRI Branch Office on Soekarno Hatta Malang exceed the expectations of customers and customers feel satisfied using products of BRI Branch Office on Soekarno Hatta Malang.

Service quality (X) has a positive effect on brand images (M2). It means that the higher the quality of service (X), the higher the brand images (M2), where the path coefficient is 0.627 with a t-value of 10.716 . 
This is because employees have sufficient knowledge to answer customer questions.

Service quality (X) has a positive effect on customer satisfaction (M1). It means that the higher the quality of service (X), the higher the customer satisfaction variable (M1), where the path coefficient is obtained is 0.421 with a t-value of 4.728 . This is because employees are serious to help solve customer problems and employees always prioritize the interests of the customers.

Based on table 5, it is known that: 1) The effect of service quality (X) on customer loyalty (Y) through customer satisfaction (M1) is 0,293 . It means customer satisfaction as mediation has a significant effect. This indicates the emergence of satisfaction felt by customers caused by the good quality of service that is felt by customers can affect the formation of customer loyalty to a particular product or service; 2) The effect of service quality $(\mathrm{X})$ on customer loyalty $(\mathrm{Y})$ through brand images (M2) is 0.029. It means brand images as mediation has an insignificant effect, because the loyal customers of BRI Branch Office on Soekarno Hatta Malang are those who repurchase the same brand, only consider the same brand and do not seek information at all about other brands. The most of customers are not too concerned with brand images to become loyal customers.

\section{Conclution}

The conclutions are: 1) The service quality variable has a positive and significant effect on customer satisfaction. It means the higher the quality of service, the higher the customer satisfaction; 2) The service quality variable has a positive and significant effect on brand images. It means that the increasing of quality service will increase the brand image; 3) The service quality variable has a positive effect on customer loyalty, but the effect is not significant; 4) The customer satisfaction variable has a positive and significant effect on customer loyalty. It means that the increasing of customer satisfaction will raise the variable customer loyalty; 5) The brand images has a positive effect on customer loyalty, but the effect is not significant; 6) The effect of service quality on customer loyalty through customer satisfaction is a significant. This indicates the emergence of satisfaction felt by customers caused by the good quality of service that is felt by customers can affect the formation of customer loyalty to a particular product or service; 7) The effect of service quality on customer loyalty through brand images is an insignificant, because the loyal customers of BRI Branch Office on Soekarno Hatta Malang are those who repurchase the same brand, only consider the same brand and do not seek information about the brand at all. others, so most customers are not too concerned with brand images to become loyal customers.

\section{REFERENCES}

Andrologi, F. (2014). Analisis Pengaruh Brand Image dan Brand Awareness Terhadap Brand Loyalty dan Dampaknya Terhadap Brand Equity. Fakultas Ekonomi dan Bisnis Universitas Dipenogoro Semarang.

Arikunto, Suharsimi. 2010. Prosedur Penelitian: Suatu Pendekatan Praktik. Jakarta: Rineka Cipta.

Ayu ,Putu Y Pusparani Ni Made Rastini, 2015 Pengaruh Kualitas Produk dan Brand Image Terhadap Kepuasan Konsumen dan Loyalitas Pelanggan Kamera Canon Digital Single Lens Reflex (DSLR) di Kota Denpasar. Fakultas Ekonomi dan Bisnis Universitas Udayana, Bali, Indonesia. Jurnal Manajemen Universitas Udayana, 3(5)

Bilson, Simmora, 2004, Riset Pemasaran, Jakarta, Gramedia Utama.

Chao, Ren-Fang. 2015. The Influence of Service Quality, Brand Image, and Customer Satisfaction on Customer Loyalty for Private Karaoke Roomsin Taiwan. The Journal of Global Business Management, 11 (1), 122-130 Cooper, Donald R dan Pamela, S. Schindler. 2006. Metode Riset Bisnis, volume 1. PT Media Global Eduksi. Jakarta.

Harianto David dan Dr. Hartono Subagio. 2013, Analisa Pengaruh Kualitas 
Layanan, Brand Image dan Atmosfer Terhadap Loyalitas Konsumen Dengan Kepuasan Konsumen Sebagai Variabel. Jurnal Manajemen Pemasaran Vol.1, No.1, 2013.

Ika, Nuruni dan Kustini. 2011. Experiental Marketing, Emotional Branding, and Brand Trust and their Effect on Loyalty on Honda Motorcycle Product. Journal of Economics, Business, and Accountancy Ventura, Vol. 14, No. 1, April 2011, pp. 19-28

Kasmir.2014. Dasar-Dasar Perbankan. Edisi Revisi, Cetakan ke duabelas, PT. Raja Grafindo Persada, Jakarta.

Kavengi Onyancha Grace, 2013. The Impact of Bank Brand Image on Customer Satisfaction and Loyalty: A Case of Kenya Commercial Bank. Jomo Kenyatta University of Agriculture and Technology, School for Human Resource Development. European. Journal of Business and Management. Vol.5, No.21, 2013. ISSN 2222-2839

Kotler, Philip and Keller. (2008). Manajemen Pemasaran. Edisi Ketigabelas. Jilid 1. Jakarta: Erlangga.

Kotler, Philip and Kevin Lane Keller. 2012. Marketing Management 13.New Jersey: Pearson Prentice Hall, Inc.

Lovenia, Christiana Okky Augusta. 2012. Analisis Pengaruh Kualitas Pelayanan terhadap Kepuasan Nasabah (Studi Kasus Pada Nasabah Bank Jateng Cabang Utama Semarang). Semarang: Universitas Diponegoro

Mukarom, Moch Syaeful. 2012. Analisis Pengaruh Nilai Nasabah dan Kualitas Pelayanan Terhadap Kepuasan Nasabah Untuk Menciptakan Loyalitas Nasabah (Studi Kasus Nasabah Bank BRI Cabang Pandanaran Semarang). Journal of Management. Volume 1 Nomer 1

Parasuraman, Valarie A. Zeithmal, and Leonard L. Berry. 1988. SERVQUAL: A Multiple-Item Scale for Measuring Consumer Perceptions of Service Quality. Journal of Retailing. Vol 64 (1) pp 12-37
Sugiyono. 2012. Metode Penelitian Kuantitatif Kualitatif dan R\&D. Bandung: Alfabet.

Undang-Undang No.10 Tahun 1998 Tentang Perubahan Atas Undang_Undang No. 7 Tahun 1992 Tentang Perbankan 